Creative Commons User License: CC BY-NC-ND

Abstracted by: EBSCOhost, Electronic Journals Service (EJS),

Google Scholar, Journal Seek, Scientific Commons,

Food and Agricultural Organization (FAO), CABI and Scopus

http://www.ajol.info/index.php/jae

http://eoi.citefactor.org/10.11226/v23i4
Journal of Agricultural Extension

Vol. 24 (1) January, 2020

ISSN(e): 24086851; ISSN(Print); 1119944X

http://journal.aesonnigeria.org

Email:

editorinchief@aesonnigeria.org

\title{
Farmers Income and Savings Pattern in Benue State, Nigeria
}

https://dx.doi.org/10.4314/jae.v24i1.13

\section{Odoh, Ngozi Ekunyi}

Department of Agricultural Economics, Management \& Extension, Ebonyi State University, P.M.B 053, Abakaliki, Ebonyi State, Nigeria

Email: ekunyiodoh@yahoo.com; +2348063633634

\section{Nwibo, Simon Uguru}

Department of Agricultural Economics, Management \& Extension, Ebonyi State University, P.M.B 053, Abakaliki, Ebonyi State, Nigeria

Email: sunwibo92@gmail.com; +2347033210710

\section{Eze, Anayochukwu Victor}

Department of Agricultural Economics, Kenyatta University, Kenya

Email: ezeanayochukwu09@gmail.com; +2348036718919

\section{Igwe, Esther Onyinyichi}

Department of Agricultural Economics, Management \& Extension, Ebonyi State University, P.M.B 053, Abakaliki.

Email: igweesther598@yahoo.com; +2348082814748

\section{Abstract}

The study analysed farmers' income and savings pattern in Benue State. Both multi-stage random and purposive sampling procedures were employed to select 140 respondents for the study. The study employed primary data which were collected through the use of the structured questionnaire. The result showed that farm size, level of access to credit, diversification of income sources, types of investment and risks inherent in the business are the major determinants of the income level of the small scale farmers. The farmers engaged in the following farm activities, crop production, hunting, fishing, gathering of forest products, marketing of agricultural products and livestock production. Meanwhile, trading, teaching, and non-farm wage labour were the main non-farm activities they engaged in. The result equally showed that farmers adopted both formal and informal savings methods but have higher preference for the informal method as indicated by their preference for savings in rotational savings and credit Association (ESUSU) and daily contribution schemes. Educational attainment, annual income, farming experience, and farm size had positive influence on the farmers' savings pattern. The test of the hypothesis indicated that the socio-economic characteristics of the small scale farmers have significant effects on the savings pattern adopted in the area. Consequently, the study recommended the establishment of banks in the rural area so as to increase farmers' savings capacity in formal sector; establishment of enlightenment programme to create awareness among the rural farmers, and introduction 
of risk reduction policy to minimize risks associated with farming, thereby encouraging farmers to remain in farming business.

Keywords: Farm activities, non-farm activities, farmers, formal and informal savings

\section{Introduction}

Savings are vital particularly in a developing economy like Nigeria, because of the direct bearing it has on the level of economic activity of such a country (Jalo, Onu, Margwa, and Dire, 2015). The level of progress attained within the agricultural sector will largely depend on what the farmers do with the incomes generated from their farming activities. If such proceeds are saved, it will make capital available for further investment in the sector. In other words, the growth rate in the farming economy largely depends on the stock of capital built in a farm organization and the plunging back of such stock in form of savings for further improvement of the farm organization. However, if these increments are spent on household expenditure without building up the necessary investment infrastructure, the future economic development of the nation will be hampered. Adequate integration of savings and income generation programmes into development strategies is capable of improving resource allocation, promoting equitable distribution of income and reducing credit delivery and recovery costs.

According to Iniguez-Montiel and Kurosaki (2018), high-level income inequality exists in developing countries, therefore understanding inequality and its consequences on agricultural production especially on how to improve the status of the chronic poverty trapped individual farmers and farming communities through credit accumulation is the major concern and focus of the study. According to the Nwibo, Nwakpu and Eze (2017), capital accumulation is a major prerequisite for economic development and if the volume of savings is inadequate to meet income requirements, major bottlenecks are likely to develop in the process of capital formulation and the drive for development. Nwibo and Mbam (2013) posited that the savings behaviour of farmers in developing countries is less dependent on the absolute level of aggregate income but more on the other factors such as the relationship between current and expected income, the nature of the business, farm size, wealth and demographic variables like age. Information on the determinants of saving patterns among farmers could help policy movers and credit agencies for effective targeting and efficient credit service delivery of financial lending schemes that could increase agricultural production as well as the general well-being of farmers.

One of the major problems confronting the development of agricultural sector in Nigeria is inadequate savings and poor access to income by the small holder farmers (Uhuegbulem, Henri-Ukoha, Osuji, Ukoha and Oshaji, 2016). Despite this problem, policymakers appear not to have drawn-up adequate and comprehensive rural savings schemes that will enable farmers to save and draw back from such accumulated capital for productive investment purposes. The major occupation of these rural dwellers is farming and it is highly important to improve the livelihood of these rural people. The situation of lack of capital has contributed in no small measure to the decline of agricultural productivity and there seems to exist no empirical research specifically targeted at improving the income holding base of the small-scale farmers, hence the need for this study. Specifically, the study set out to 
achieve the following objectives: identify the factors that determined the level of income of the small-scale farmers; compare the level of income from farm and non-farm activities in the study area; identify various savings method adopted by the farmers, and determine the effects of socio-economic characteristics of the small-scale farmers on their savings pattern.

\section{Methodology}

This study was carried out in Benue State, North Central, Nigeria. Benue State has 23 Local Government Areas It is located along latitudes $6^{0} 25 / \mathrm{N}$ and $8^{0} 8 / \mathrm{N}$ as well as longitudes $7^{\circ} 47^{\prime} \mathrm{E}$ and $10^{\circ} \mathrm{E}$ (Okeke, Nto and Mbanasor, 2015). The population of the State is estimated to be 4,253,641 million people based on 2006 census report and a total landmass of $34,059 \mathrm{~km}^{2}$. Benue State shares boundary with Nassarawa, Kogi, Enugu and Taraba states. The State is located in the guinea savannah vegetation zone. The state enjoys a tropical climate with two distinct seasons, namely: rainy season which starts from April to October, and dry season which lasts from November to March. The state stretches across the transition belt between forest and savannah vegetation. The State is inhabited mainly by Tiv, Idoma and Igede people who speak their respective languages. The State is rich in agricultural activities because of the rich fertile soil which support growth of crops and this constitutes the major occupation of the people. The popular grown crops are: yam, cassava, rice, sweet potatoes, soya bean, guinea corn, sesame, ground nut and oil palm.

Multi-state random and purposive sampling procedures were employed to select respondents for this study. To ensure equal representation of the local government areas (LGAs) in the three agricultural zones, 30 percent of the LGAs were selected. Based on this, the share of 30 percent in Benue North East and North West respectively were 2 LGAs while 3 LGAs was obtained in Benue South and this give rise to a total of seven (7) LGAs (Table 1). Furthermore, five (5) communities/districts were purposively selected based on the volume of agricultural activities in these communities/districts, making a total of 35 communities/districts. From the thirty five (35) communities/districts, four (4) farmers were randomly selected to sum up to a total of 140 respondents that were used for the study. Primary data were collected through the use of structured questionnaire. Data collected were analyzed using both descriptive and inferential statistics. 
Creative Commons User License: CC BY-NC-ND

Abstracted by: EBSCOhost, Electronic Journals Service (EJS),

Google Scholar, Journal Seek, Scientific Commons,

Food and Agricultural Organization (FAO), CABI and Scopus

http://www.ajol.info/index.php/jae

http://eoi.citefactor.org/10.11226/v23i4
Journal of Agricultural Extension

Vol. 24 (1) January, 2020

ISSN(e): 24086851; ISSN(Print); 1119944X

http://journal.aesonnigeria.org

Email: editorinchief@aesonnigeria.org

Table 1: Sampled local government areas and communities

\begin{tabular}{|c|c|c|c|c|}
\hline $\begin{array}{l}\text { Agricultural } \\
\text { zone }\end{array}$ & $\begin{array}{l}\text { No. of Local } \\
\text { Government Areas } \\
\text { (LGAs) }\end{array}$ & $\begin{array}{l}\text { Sampled Local } \\
\text { Government } \\
\text { Areas }\end{array}$ & $\begin{array}{l}\text { Selected } \\
\text { Communities }\end{array}$ & $\begin{array}{l}\text { No. of } \\
\text { respondents }\end{array}$ \\
\hline \multirow[t]{11}{*}{$\begin{array}{l}\text { Benue } \\
\text { Southern }\end{array}$} & \multirow[t]{11}{*}{$\begin{array}{l}\text { Ado, Agatu, Apa, } \\
\text { Obi, Ogbadibo, } \\
\text { Ohimini, Oju, } \\
\text { Okpokwu, Otukpo }\end{array}$} & Ado & $\begin{array}{l}\text { ljigbam, } \\
\text { Ikponkpon, } \\
\text { Ogbee, } \\
\text { Osukpo, } \\
\text { Achibila. }\end{array}$ & $\begin{array}{l}4 \\
4 \\
4 \\
4 \\
4\end{array}$ \\
\hline & & \multirow[t]{5}{*}{ Ohimini } & Ogodu, & 4 \\
\hline & & & Enumona, & 4 \\
\hline & & & Ogoli, & 4 \\
\hline & & & Umonomi, & 4 \\
\hline & & & lyaya, & 4 \\
\hline & & \multirow[t]{5}{*}{ Obi } & Adudu, & 4 \\
\hline & & & Agwatashi, & 4 \\
\hline & & & Akanga, & 4 \\
\hline & & & Uwokwu & 4 \\
\hline & & & Ito & 4 \\
\hline \multirow{10}{*}{$\begin{array}{l}\text { Benue North } \\
\text { West }\end{array}$} & \multirow{10}{*}{$\begin{array}{l}\text { Buruku, Gboko, } \\
\text { Guma, Gwer-East, } \\
\text { Gwer-West, } \\
\text { Markurdi, Tarka }\end{array}$} & \multirow[t]{5}{*}{ Guma } & Mbagwen & 4 \\
\hline & & & Uyiev, & 4 \\
\hline & & & Daudu, & 4 \\
\hline & & & Torkula, & 4 \\
\hline & & & Kase-yough, & 4 \\
\hline & & \multirow{5}{*}{ Gwer-East } & Yonor, & 4 \\
\hline & & & Ngyonov, & 4 \\
\hline & & & $\begin{array}{l}\text { Njiriv, } \\
\text {, }\end{array}$ & 4 \\
\hline & & & Raav, & 4 \\
\hline & & & Mbakpa & 4 \\
\hline \multirow{10}{*}{$\begin{array}{l}\text { Benue North } \\
\text { East }\end{array}$} & Katsina-Ala, & \multirow[t]{5}{*}{ Kwanda } & Nanev, & 4 \\
\hline & Konshisha, & & Turan, & 4 \\
\hline & Kwande, Logo, & & Ahile/Akende, & 4 \\
\hline & Ukum, Ushongo, & & Ahundu, & 4 \\
\hline & Vandeikya & & & 4 \\
\hline & & \multirow[t]{5}{*}{ Ukum } & Borikyo, & 4 \\
\hline & & & Aterayange, & 4 \\
\hline & & & Mbatian, & 4 \\
\hline & & & Uvan, Ituuluv, & 4 \\
\hline & & & Ugbadan & 4 \\
\hline Total & 23 & 7 & 35 & 140 \\
\hline
\end{tabular}


Creative Commons User License: CC BY-NC-ND

Abstracted by: EBSCOhost, Electronic Journals Service (EJS),

Google Scholar, Journal Seek, Scientific Commons,

Food and Agricultural Organization (FAO), CABI and Scopus

http://www.ajol.info/index.php/jae

http://eoi.citefactor.org/10.11226/v23i4
Journal of Agricultural Extension

Vol. 24 (1) January, 2020

ISSN(e): 24086851; ISSN(Print); 1119944X

http://journal.aesonnigeria.org

Email:

\section{Effects of Socio-Economic Characteristics of Small-Scale Farmers on Savings Pattern}

OLS multiple regression model was applied to determine the effects of socio-economic characteristics of the small-scale farmers on their savings pattern. Diagnostics tests were carried out to ensure that the data used for the analysis meet the basic multiple linear regression assumptions, thereby making the result reliable (Eze and Nwibo, 2014). The assumptions and the respective diagnostics tests applied are:

i. Multicollinearity: Variance Inflation Factor (VIF) values were used to test the present or otherwise of multicollinearity in the data. For the assumption to be met, VIF values must be below 10, and tolerance scores to be above 0.2 .

ii. Autocorrelation: Durbin-Watson statistic was used to test the presence of autocorrelation (i.e. values of the residuals are independent or uncorrelated). For this assumption to be met, the Durbin Watson value has to be close to \pm 2.0 .

iii. Homoscedasticity: To test if the variance residuals (or amount of error in the model) are similar across the values of the independent variables (homoscedasticity), plot of standardized residuals against predicted values was used.

$Y=\alpha o+\beta_{1} X_{1}+\beta_{2} X_{2}+\beta_{3} X_{3}+\beta_{4} X_{4}+\beta_{5} X_{5}+\beta_{6} X_{6}+\beta_{7} X_{7}+$ et - - - - Explicit stochastic

Where;

$\mathrm{Y}=$ Farmers' savings capacity ( $\mathrm{N})$

Table 2: Description of predictor variables and a priori expectation

\begin{tabular}{lllc}
\hline $\begin{array}{l}\text { Variable } \\
\text { code }\end{array}$ & Description of variable & Method of measurement & $\begin{array}{c}\text { Expected } \\
\text { sign }\end{array}$ \\
\hline $\mathrm{X}_{1}$ & $\begin{array}{l}\text { Age of the farmers } \\
\text { Marital status }\end{array}$ & $\begin{array}{l}\text { Age of the farmers in years } \\
\text { Single }=1 \text {, married }=2, \\
\text { divorced }=3 \text {, separated }=4\end{array}$ & - \\
$\mathrm{X}_{2}$ & or - & \\
$\mathrm{X}_{3}$ & Educational level & $\begin{array}{l}\text { Number of years spent } \\
\text { schooling }\end{array}$ & + \\
$\mathrm{X}_{4}$ & Annual Income & Naira & + \\
$\mathrm{X}_{5}$ & Farming Experience & Number of years in farming & + \\
$\mathrm{X}_{6}$ & Household size & Number & + \\
$\mathrm{X}_{7}$ & Farm size & Hectare & + \\
aO & Constant & & + \\
$\beta_{1}-\beta_{7}$ & Regression coefficients & & \\
Et & Stochastic error term & & \\
\hline
\end{tabular}

\section{Results and Discussion}

\section{Factors Determining Income Level of Farmers}

The factors determining income level of the farmers as presented in Table 3 shows that the size of farm (64.3\%); level of access to credit $(60.0 \%)$, employment status $(54.3 \%)$, diversification of income sources (52.9\%); types of investments $(50.7 \%)$; and risk inherent in the business (46.4\%). Farming is the primary livelihood source of a farmer. Thus, farmer who cultivates large farms stands a better chance of expanding his income generation. This is in consonance with the finding of Lowder, Skoet and Raney (2016) who affirmed 
that the larger the farm size cultivated by farmers, the higher the level of income from the investment. Also, the high level of access to credit indicates that credit is an important productive asset that can facilitate investments in farm and non-farm sectors for the purpose of increasing the income level of the farmers. Access to credit is critical to enhancing productivity in agricultural and non-agricultural enterprises (Nwibo, Okonkwo, Eze, Mbam and Odoh, 2019). Farm enterprises require unhindered access to credit to boost their economic activities. This is predicated on the fact that credit serves as the engine that drives other factors of production to attain higher level of growth. The study also shows that some farmers tend to diversify income sources through investment in nonfarm activities because investments in this section are less risky than those of the farm sector. The vagaries nature of agriculture especially in Nigeria have forced many farmers to diversified into non-farm enterprises as a way of minimizing risk and increasing income generation. In line with this assertion, Nwibo et al. (2017) averred that Nigerian farmers have diversified their income sources from farm activities to non-farm activities due to risk and uncertainties that characterise agricultural activities.

Table 3: Factors determining their income level

\begin{tabular}{ll}
\hline Factors & Percentage $(\mathbf{n = 1 4 0})$ \\
\hline Farm size & 64.3 \\
Household size & 33.6 \\
Purchasing power & 31.4 \\
Employment status & 54.3 \\
Diversification of income source & 52.9 \\
Types of investment & 50.7 \\
Risk inherent in the business & 46.4 \\
Level of access to credit & 60.0 \\
\hline
\end{tabular}

\section{Income Generation Activities from Farm and Non-Farm Sector}

In the farm sector, majority of the farmers $(56.4 \%)$ engaged in crop production while $38.6 \%$ engaged in fishing, hunting, and gathering of forest products (Table 4). Also, 34.3\% of them are involved in the marketing of agricultural products, while $31.4 \%$ of them are involved in livestock production. The engagement of high number of the respondents in farming activities is justified on the ground that Benue State is mainly an agrarian State and this has earned it the title of 'food basket of the nation'. Therefore, farming activities constitute the major source of income for the inhabitants. The farmers' earned an average

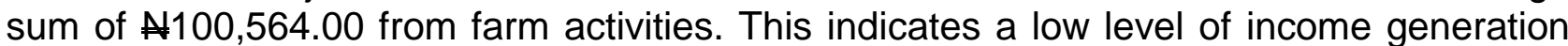
from farm activities in the study area. This development may have prompted the farmers to diversify their livelihood to non-farm activities in their bid to complement income from farm. Further analysis of the non-farm sector, indicates that's 30\% of the farmers were also involved in trading, $21.4 \%$ were into teaching, $12.9 \%$ of them are engaged in non-farm wages labour, and about $10.7 \%$ of them are self -employed. This finding collaborates that of Odoemenem, Ezihe and Akerele (2013) who reported that majority of small scale farmers in Benue State were involved in trading, teaching and other activities as way of increasing income generation for higher savings investment. The farmers earned an average annual income of $\mathbf{N 1 6 4 , 6 9 8 . 0 0}$ from their non-farm activities; implying that the farmers earn higher income from non-farm activities despite the fact that majority of them 
considered these activities as secondary occupation. This finding is justified by that of Odoh and Nwibo (2016) who posit that non-farm sector is a major contributor to employment and income generation of rural households, contributing up to $63 \%$ of household income in Nigeria. Similarly, Nwibo et al. (2017) assert that non-farm income is important to the rural household because farm income obtained by poorer households is barely enough to meet family needs due to landlessness or because they own/lease little farm land.

Table 4: Income generation from farm and non -farm activities

\begin{tabular}{|c|c|c|c|}
\hline Sector activities & Sources of income & Percentage & Income share (A) \\
\hline \multirow[t]{6}{*}{ Farm } & Crop production & 56.4 & $27,244.4$ \\
\hline & Livestock production & 31.4 & $15,224.8$ \\
\hline & Processing of farm products & 27.9 & $13,221.6$ \\
\hline & $\begin{array}{l}\text { Hunting, fishing and forest } \\
\text { products gathering }\end{array}$ & 38.6 & $18,430.1$ \\
\hline & Farm wage labour & 20.7 & $10,016.3$ \\
\hline & $\begin{array}{l}\text { Marketing of agricultural } \\
\text { products }\end{array}$ & 34.3 & $16,426.8$ \\
\hline \multicolumn{3}{|c|}{ Total average income } & N100,564 \\
\hline \multirow[t]{8}{*}{ Non-farm } & Self-employment & 10.7 & $19,527.7$ \\
\hline & Public service & 1.4 & $23,004.3$ \\
\hline & Rentals & 5.7 & $10,514.9$ \\
\hline & Non-farm wage labour & 12.9 & $22,531.7$ \\
\hline & Remittance cash inflow & 0.7 & $5,000.0$ \\
\hline & Trading & 30.0 & $45,063.9$ \\
\hline & Teaching & 21.4 & $39,055.4$ \\
\hline & \multicolumn{2}{|c|}{ Total average income } & N164,698 \\
\hline
\end{tabular}

Methods of Savings Employed by the Respondents

There are two saving methods applied by the farmers - formal and informal methods. Analysis of the formal method indicates that $31.4 \%$ of them preferred saving in cooperative societies, followed by $20.0 \%$ who preferred saving in the Bank of Agriculture (BOA) while $17.9 \%$ of them use the conventional banking system (Table 5). None of the farmers made saving with the Microfinance banks. Furthermore, the informal sector shows that the proffered saving method employed by the small scale farmers were rotatory savings and credit association (Esusu) $45.7 \%$. This is likely due to the ease associated with money savings in this association. More so, no formal processing procedure is required and often times, no security is required to access credit while the savings are made available to the depositor on very short notice. This is in line with the findings of the Odoemenem et al. (2013) who reported that majority of farmers in Benue state make use of informal financial sectors to mobilize savings and develop their rural communities because it gives them access to loans that they cannot get from formal financial institutions due to lack of collateral. 
Table 5: Methods of savings practiced in the area

\begin{tabular}{lll}
\hline Method of Savings & Description of variables & Percentage \\
\hline Formal & Conventional banks & 17.9 \\
& Microfinance banks & 2.9 \\
& Bank of Agriculture & 20.0 \\
& Mobile banking & - \\
Cooperative society & 31.4 \\
Informal & Rotating saving and credit association & 45.7 \\
& (Esusu) & 10.0 \\
& Friends and relatives & 7.9 \\
& Religious groups & 43.6 \\
\hline
\end{tabular}

\section{Effects of Socioeconomic Characteristics of the Small Scale Farmers on their Savings}

Diagnostics tests were carried out to determine the reliability of the data used for this analysis. Three basic diagnostics tests were conducted, namely: multicollinearity, autocorrelation, and homoscedasticity. The test of multicollinearity using the values of Variance Inflation Factor (VIF) indicates that the values of the independent variables were below 10 while the tolerance statistics were above 0.2 . These values attest to no multicollinearity in the model, thus, the assumption that the predictor variables are not correlated with one another was met. The Durbin Watson statistics was 1.793, signifying absence of autocorrelation in the model. This follows that Durbin Watson value has to be close to \pm 2.0 for the assumption to be met, which is the case in this analysis. To test if the variance residuals are similar across the values of the independent variables (homoscedasticity), plot of standardized residuals against predicted values was observed and the variation in the residuals values appears to be roughly similar, confirming absence of homoscedasticity, thus, meeting the assumption.

The result in Table 6 shows an R-Squared $\left(R^{2}\right)$ value of 0.728 which shows that $72.8 \%$ of the variation in the savings pattern of farmers in the study area was accounted for by the included independent variable all put together (age, marital status, educational level, animal income, farming experience, household size, and farm size). The goodness of fit is confirmed by the F- statistics value of 4.099 which was statistically significant at $(P<0.05)$. The coefficient of age was negatively sign but statistically significant at $1 \%$, implying that the size of savings declines as farmers advances in age. Marital status was negatively signed but statistically significant implying that getting to marriage decreases the size of farmers' savings. Educational qualification shows a positive coefficient but not statistically significant. This implies that as the farmers acquire higher levels of education, they are more likely to adopt greater savings patterns and increase their savings for future investment. This finding is in line with Akerele and Ambali (2012) who posited that an increase in years spent in acquiring formal education implies an increase in the level of savings of the rural farmers. The annual income of the farmers had a positive coefficient at a $5 \%$ level. This implies that as farmers generate higher income annually; it increases their marginal propensity to save. This is in line with Osondu, Obike and Ogbonna (2015) who posited that the farmers' ability to save depends on their level of income. Farming 
Creative Commons User License: CC BY-NC-ND

Abstracted by: EBSCOhost, Electronic Journals Service (EJS),

Google Scholar, Journal Seek, Scientific Commons,

Food and Agricultural Organization (FAO), CABI and Scopus

http://www.ajol.info/index.php/jae

http://eoi.citefactor.org/10.11226/v23i4
Journal of Agricultural Extension

Vol. 24 (1) January, 2020

ISSN(e): 24086851; ISSN(Print); 1119944X

http://journal.aesonnigeria.org

Email:

editorinchief@aesonnigeria.org

experience equally had a positive coefficient but was statistically insignificant, indicating that the more farming experience a farmer acquires over the years, the higher the savings pattern he will adopt. Household size was negatively signed and was not statistically significant. This implies that increases in the household size of the farmers will lead to decreases in the size of their savings. Farm size had a positive coefficient and was statistically significant at a $5 \%$ level. This implies that an increase in the farm size of farmers will lead to an increase in the amount and pattern of savings of the farmer.

Table 6: Effects of socio - economic characteristics of the farmers on their saving pattern

\begin{tabular}{lccc}
\hline Variables & Coefficient & $\begin{array}{l}\text { Standard } \\
\text { Error }\end{array}$ & t-value \\
\hline Constant & 3.232 & 0.702 & $4.601^{*}$ \\
Age & -0.065 & 0.015 & -4.217 \\
Marital Status & -0.874 & 0.287 & $-3.042^{\star}$ \\
Educational Level & 0.070 & 0.94 & 0.747 \\
Annual income & 2.066 & 0.000 & $1.176^{*}$ \\
Farming experience & 0.022 & 0.21 & 1.048 \\
Household size & -0.051 & 0.034 & -0.154 \\
Farm size & 0.004 & 0.007 & $0.655^{\star}$ \\
$\mathrm{R}$ & 0.878 or 87.8 & & \\
$\mathrm{R}^{2}$ & 0.728 or 72.8 & & \\
Adj. $\mathrm{R}^{2}$ & 0.672 or 67.2 & & \\
F-statistics & 4.099 & & \\
Standard error & 1.34577 & & \\
Durbin Watson & 1.793 & & \\
\hline
\end{tabular}

${ }^{*} \mathrm{P} \leq 0.05$

\section{Conclusion and Recommendations}

The study established that the factors that determined income level of the farmers are size of farm, level of access to credit, employment status, diversification of income sources, types of investments, and risk inherent in the business. The major farming activities of the farmers are: crop production, and fishing, hunting, and gathering of forest products while trading, teaching, and non-farm wages labour constitute the non-farming activities. The mean annual income from farming activities was $\$ 100,564.00$ which is $24.2 \%$ lesser than

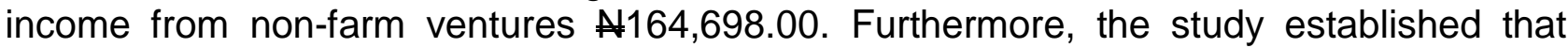
there are two saving methods applied by the farmers - formal and informal methods. However, the farmers showed preference in informal savings, particularly the rotatory savings and credit association (ESUSU) and the daily contribution scheme in the area because of the ease associated with savings in these associations. The coefficients of educational level, annual income, farming experience, and farm size were found to positively influence savings pattern of the farmers. To increase farmers' savings capacity in formal financial sector, financial institutions should consider establishing banks in the rural area; farmers on their own part should form co-operative societies so as to enhance their access to credit facilities from formal financial institutions. Government should consider introduction of risk reduction policy to minimise risks associated with farming 
editorinchief@aesonnigeria.org

activities.

\section{Reference}

Akerele, E.G and Ambali, O.I. (2012). Consumption and saving pattern among rural farming households in Abeokuta North Local Government Area of Ogun State. Journal of Agriculture and Veterinary Science, 3:53-62.

Eze, A.V. and Nwibo, S.U. (2014). Economic and technical efficiency of cassava production in lka North East Local Government Area of Delta State, Nigeria. Journal of Development and Agricultural Economics, 6(10): 429-436. DOI: 10.5897/JDAE2013.0541

Iniguez-Montiel, A.J. and Kurosaki, T. (2018). Growth, inequality and poverty dynamics in Mexico. Latin American Economic Review, 27(12), 1-25. https://doi.org/10.1186/s40503-018-0058-9

Jalo, J. N., Onu, J. I., Margwa, R. S. and Dire, B. (2015). Effects of socio-economic characteristics on savings among farmers in cooperative societies: Observations from Numan and Demsa Local Government Area of Adamawa State, Nigeria. Journal of Agricultural and Crop Research, 3(7), 117-122.

Lowder, S.K., Skoet, J. and Raney, T. (2016). The number, size, and distribution of farms, smallholder farms, and family farms worldwide. World Development, 87: 16-29.

Nwibo, S.U. and Mbam, B.N. (2013). Determinants of Savings and Investment Capacities of Farming Households in Udi Local Government Area of Enugu State, Nigeria. Research Journal of Finance and Accounting. 4(15): 59-68.

Nwibo, S. U., Okonkwo, T. O., Eze, A. V., Mbam, B. N. and Odoh, N. E. (2019). Effect of Microcredit on Poverty Reduction among Rural Farm Households in Northeast, Nigeria. Asian Journal of Agricultural Extension, Economics \& Sociology, 35(2): 1-9, 2019. https://doi.org/10.9734/ajaees/2019/v35i230218

Nwibo, S.U., Nwakpu, C. and Eze, A.V. (2017). Income and Investment Portfolio of Smallholder Farmers in Ezza South Local Government Area of Ebonyi State, Nigeria. European Journal of Scientific Research, 145(3) 328 - 335.

Odoemenem, I.U., Ezihe, J.A.C. and Akerele, S.O. (2013). Saving and Investment Pattern of Small-Scale Farmers of Benue State, Nigeria. Global Journal of Human Social Science, 13(1): 6-12.

Odoh, N.E and Nwibo, S.U. (2016). Linkage effects of Rural Non-Farm Income Diversification on Poverty Reduction among Farm Households in South-East Nigeria. International Journal of Science and Research, 5(5):350-355

Okeke, A.M., Nto, P.O. and Mbanasor, J.A. (2015). Analysis of the Factors Influencing Savings and Investment Behaviour among Yam Entrepreneurs in Benue State, Nigeria. European Journal of Business and Management, 7(27), 205- 209.

Osondu, C.K., Obike, K.C. and Ogbonna, S.I. (2015). Savings, income and investment patterns and its determinants among small holder arable crop farmers in Umuahia Capital Territory, Abia State Nigeria. European Journal of Business and Innovation Research, 3(1), 51-70.

Unuegbulem, I.J., Henri-Ukoha, A., Osuji, M.N., Ukoha, I.I., Oshaji, I.O. (2016). Determinants of savings among small-scale food crop farmers in Owerri West Local Government Area of Imo State, Nigeria. Journal of Agriculture and Social Research (JASR), 16(2), 16-24. 